\title{
Enhanced Lactone Stability of CZ48 in Blood Correlates to its Lack of Toxicity in Mice
}

\author{
Xing Liu ${ }^{1}$, Yang Wang ${ }^{1}$, Zhisong $\mathrm{Cao}^{1}$, Max Zhan ${ }^{2}$, Dana Vardeman ${ }^{1}$, and Beppino Giovanella ${ }^{1}$ \\ ${ }^{1} 10301$ Stella Link Road, Houston, Texas 77025, USA. \\ ${ }^{2}$ Department of Pharmaceutical Sciences, College of Pharmacy, University of Kentucky, 741 South Limestone, \\ Lexington, KY, USA. \\ Received, March 18 ${ }^{\text {th }}, 2013$; Revised, March 25 ${ }^{\text {th }}, 2013$; Accepted, May $6^{\text {th }}, 2013$; Published, May $7^{\text {th }}, 2013$.
}

\begin{abstract}
Purpose. The aim of this study was to correlate the relationship between the pharmacokinetic behaviors and the toxicity of a new investigational anticancer agent CZ48, a C20propionate ester of camptothecin (CPT) in mice. Methods. In this study, the safety and pharmacokinetics of oral doses of CZ48 were compared with the oral doses of CPT. Mice were administered orally one of three single doses of CZ48 (50, 200 and $1000 \mathrm{mg} / \mathrm{kg})$ and two single doses of CPT $(1.5 \mathrm{mg} / \mathrm{kg}$ and 6.0 $\mathrm{mg} / \mathrm{kg}$ ). Blood samples were collected from all mice at the defined time points after drug administration for assessment of plasma CZ48 and CPT concentrations. Results. The study showed that CZ48 was very stable in mouse blood and the majority of this agent stayed intact as the lactone form when in circulation, with only a small fraction of the CZ48 molecules metabolized into CPT. The concentration of the metabolite CPT measured in the mouse blood was only 3\% of the concentration found for the maximum tolerated dose $(6.0 \mathrm{mg} / \mathrm{kg})$ of plain CPT. The stability difference between CZ48 and CPT in blood was structurally explained by the geometry of these two molecules. Conclusion. The lack of toxicity of CZ48 at effective doses in mice is attributed to its enhanced stability in their blood.
\end{abstract}

This article is open to POST-PUBLICATION REVIEW. Registered readers (see "For Readers") may comment by clicking on ABSTRACT on the issue's contents page.

\section{INTRODUCTION}

Human topoisomerase I is an important target for cancer therapies (1-3). Camptothecin (CPT) compounds, cytotoxic quinoline alkaloids, are well-established topoisomerase 1 inhibitors showing great activity against a broad spectrum of cancers. CPT analogues irinotecan and topotecan have been approved and are used for treating various types of cancer (4-9). Two major digestive toxicities, a cholinergic syndrome and a delayed diarrhea, are seen in patients treated with intravenous irinotecan $(10,11)$. The cholinergic syndrome could be attributed to high plasma concentrations of 7ethyl-10-hydroxycamptothecin (SN38). The local effects of SN38 in the small bowel are thought to be responsible for the late diarrhea $(12,13)$. The dose-limiting toxicities of irinotecan are delayed diarrhea as well as neutropenia. A major toxicity in patients treated with intravenous topotecan is myelosuppression (14). In our laboratory, CPT itself wiped out every human xenograft transplanted into nude mice. The positive results obtained from a phase 1 human clinical trial with oral CPT were only a small fraction of what achieved by this agent in mice. The instability of the CPT molecule in human blood has been thought to be responsible for the low response rate. Human serum albumin (HSA) catalyzes the opening of the lactone moiety of the CPT molecule $(15,16)$. The open form of the CPT molecule loses $90 \%$ of its anticancer activity, but maintains (or gains) the toxicity. A large number of CPT derivatives have been developed in attempts to improve their therapeutic/pharmacologic profiles. The design of novel CPT derivatives aims at overcoming the primary limitations of known CPT compounds, including lactone instability,

Corresponding Author: Zhisong Cao, PhD, CHRISTUS Stehlin Foundation for Cancer Research, 10301 Stella Link Road, Houston, TX. E-mail: zcao@stehlin.org 
reversibility of the drug interaction in the cleavable complex, and drug resistance (17-21). More information about the pharmacology and antitumor activity of the camptothecin analogues can be found in a review by Garcia-Carbonero and Supko (22).

In order to find better CPT analogues for biological evaluation, we have synthesized and tested various CPT ester derivatives in our laboratory (23-26). Among these ester compounds, CZ48 (a C20-propionate ester of CPT) has demonstrated strong anticancer activity against human tumor xenografts grown in nude mice with an exceptional lack of toxicity (27). The structure of this compound is shown in Figure 1. CZ48 is currently being tested in phase 1 human clinical trial for treating cancer patients resistant to all available chemotherapies. To better understand the reason why CZ48 is nontoxic in mice at the effective doses, we have performed several studies including metabolism, biodistribution, and pharmacokinetics. The results of metabolism and biodistribution were previously reported $(28,29)$. In this study, we analyzed the pharmacokinetic (PK) data of CZ48 with three oral doses in mice based on mean concentrations at the sampling time-point, and also the PK data at the effective and maximum tolerated doses of CPT. The comparison of PK data between CZ48 and CPT showed that the CPT concentration from each CZ48 dose was much lower than the required level for showing toxicity in mice. Thus, CZ48 was nontoxic in mice at all effective dose levels.

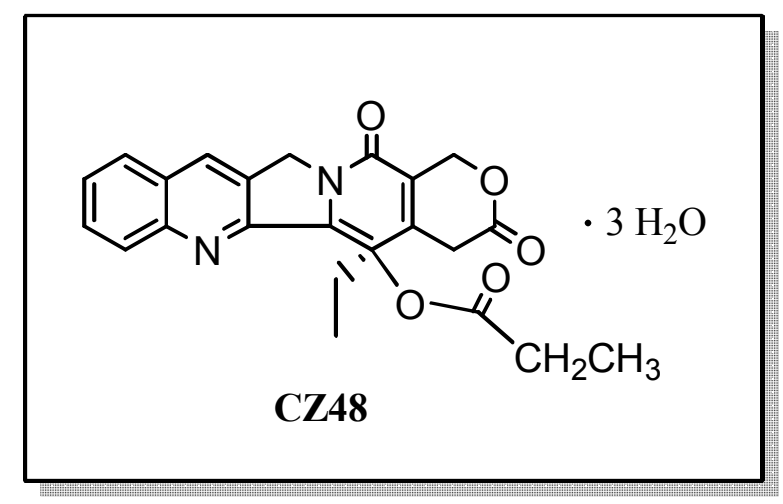

Figure 1. The molecular structure of CZ48.

\section{MATERIALS AND METHODS}

HPLC-grade acetic acid, DMSO, acetonitrile, dichloromethane and diethyl ether were obtained from Sigma-Aldrich (St. Louis, MO, USA). Chromatographic-grade water was produced by a Millipore Milli-Q system (Billerica, MA, USA). CZ48 and CZ44 were synthesized inhouse by using the reported procedures (23). Camptothecin (with a purity of 99\%) was purchased from Harbin Foran High-Tech Development Co. (Harbin, Heilongjiang, China).

\section{Preparation of CPT plasma samples}

Female nude mice (20-30 g) were randomized into two groups, each consisting of 4 animals. One group was orally administered with the maximum tolerated dose of CPT $(6.0 \mathrm{mg} / \mathrm{kg})$, and other group with the effective dose (1.5 $\mathrm{mg} / \mathrm{kg}$ ). Blood samples, collected by cardiac puncture from anesthetized mice, were placed into tubes containing sodium heparin at time points of $0.5,1.0,2.0,4.0,5.0,6.0$ and $8.0 \mathrm{hr}$. The red blood cells were removed using a centrifuge process and the plasma was immediately stored at $-80^{\circ} \mathrm{C}$ prior to analysis.

\section{Preparation of CZ48 plasma samples}

Three groups of female nude mice, with each having 4 animals, were administered oral CZ48 at three different doses, $1000 \mathrm{mg} / \mathrm{kg}, 200 \mathrm{mg} / \mathrm{kg}$, and $50 \mathrm{mg} / \mathrm{kg}$ (one group per dose level). With the same procedure described above, CZ48 plasma samples of all the defined time points $(0.5,1,2,4,5,6,8,12$, and $24 \mathrm{~h})$ were obtained and stored at $-80^{\circ} \mathrm{C}$ prior to analysis.

\section{Determination of the plasma concentrations of CZ48 and CPT}

After being thawed on ice for approximately 20 minutes, 100ul of the plasma samples were taken from the tube and added to the mixture of 100ul 1\% acetic acid and 100 ul CZ44 solution (400 ng/ml, internal standard). After thoroughly mixing with a shaker for a few minutes, the mixture was extracted with $1 \mathrm{ml}$ diethyl ether (3 times, $1 / 3 \mathrm{ml} /$ per time). The combined extracts were transferred to a clean tube and evaporated to dryness using an evaporator at $40{ }^{\circ} \mathrm{C}$ under a stream of nitrogen. The residue was reconstituted in $200 \mathrm{ul}$ of acetonitrile for HPLC 
analysis. The calibration curve was established for each determination using 100 ul of mouse plasma containing $5-1000 \mathrm{ng} / \mathrm{ml}$ for CPT and $10-1000 \mathrm{ng} / \mathrm{ml}$ for CZ48. The limit of quantification was $5 \mathrm{ng} / \mathrm{ml}$ for CPT and 10 $\mathrm{ng} / \mathrm{ml}$ for CZ48. The detailed HPLC procedure was previously reported (30).

\section{Calculation of important pharmacokinetic parameters}

Pharmacokinetic parameters were determined from the plasma concentration-time curve. The elimination half-life $\left(t_{1 / 2}\right)$ was calculated with the non-compartmental model of TOPFIT program on a personal computer. The area under the plasma concentration-time curve from zero to the last measurable plasma concentration point $(\mathrm{t}=24.0 \mathrm{~h})\left(\mathrm{AUC}_{0-\mathrm{t}}\right)$ was calculated by the linear trapezoidal method. Extrapolation to time infinity $\left(\mathrm{AUC}_{0-\infty}\right)$ was calculated as follows: $\mathrm{AUC}_{0-\infty}=\mathrm{AUC}_{0-\mathrm{t}}+\mathrm{C}_{\mathrm{t}} / \mathrm{k}_{\mathrm{e}}$, where $\mathrm{C}_{\mathrm{t}}$ is the last measurable plasma concentration and $\mathrm{k}_{\mathrm{e}}$ is the elimination rate constant.

\section{Determination of $\mathrm{CZ48 \%}$ from mouse feces from 0 to $24 \mathrm{~h}$ after drug administration}

Four different doses, 100, 500, 1000, and 2000 $\mathrm{mg} / \mathrm{kg}$, of CZ48 were chosen for the excretion study. Four groups of nude mice, 3 animals in each group with similar age and weight, were fasted overnight. Each fasted group was then orally administered with one dose. The feces of each mouse of each group were collected accumulatively for a period of 0 to $24 \mathrm{~h}$ after drug administration. For the group with 2000 $\mathrm{mg} / \mathrm{kg}$, the feces of each mouse were also collected for the subsequent $24 \mathrm{~h}$ period. After drying at $60{ }^{\circ} \mathrm{C}$ for $48 \mathrm{~h}$, the feces from each animal was weighed with an electronic balance having an accuracy of $0.1 \mathrm{mg}$. The dried feces were finely ground with an agate mortar and a pestle. A sample of $50 \mathrm{mg}$ finely ground feces was placed into a $15 \mathrm{ml}$ centrifuge tube, to which $100 \mu \mathrm{l}$ of internal standard solution (CZ44, $500 \mu \mathrm{g} / \mathrm{ml}), 0.5 \mathrm{ml}$ acetonitrile, and 4.4 $\mathrm{ml}$ dichloromethane were added. After shaking on a Maxi-Mix Mixer for $1 \mathrm{~min}$, the mixture was allowed to mix ultrasonically for $30 \mathrm{~min}$. To be extracted completely, the mixture was then placed on a Platform Mixer and allowed to shake at speed of $10 \mathrm{rpm}$ for $1 \mathrm{~h}$. After the precipitation of the feces, $2 \mathrm{ml}$ of top extract suspension was taken by pipet and placed into a centrifuge tube. After centrifuging at $13000 \mathrm{rpm}$ for $15 \mathrm{~min}, 500 \mu \mathrm{l}$ of supernatant was removed and placed into $1.5 \mathrm{ml}$ test tube and dried under air stream. The residue was re-dissolved in 500 $\mu l$ acetonitrile. After the second centrifugation, the acetonitrile solution was ready for analysis.

\section{HPLC analysis of the fecal samples}

The HPLC procedure for measuring CZ48 was previously reported (30). Briefly, a Varian C8 column was used for chromatography with $0.1 \%$ ultrapure water as the mobile phase $\mathrm{A}$ and acetonitrile as the mobile phase $\mathrm{B}$. The flow rate of elution was $1.2 \mathrm{ml} / \mathrm{min}$. CZ48 was detected with an UV detector at $254 \mathrm{~nm}$ within the retention time range of 12.1-12.2 $\mathrm{min}$.

\section{Computational modeling}

Gaussian03 program (31) was used to optimize the geometries of CPT and CZ48 at the B3LYP/6-31G* level. All calculations were performed on an IBM supercomputer at the computer center of the University of Kentucky.

\section{STATISTICAL ANALYSIS}

Each determining time point was measured 3 times. Values measured for CZ48 and metabolite CPT plasma levels appearing in plotted figures are presented as the arithmetic means \pm the standard error of the mean (SEM). Means are presented to three significant figures with SEM values presented to the same precision. Calculated $\mathrm{C}_{\max }$ and $\mathrm{AUC}$ values were subjected to one-way analysis of variance (ANOVA) using SigmaPlot version 12.0 (Systat Software Inc., San Jose,CA). In cases where an ANOVA determined a statistically significant difference $(p<0.05)$ among the means, a Turkey pairwise multiple comparisons test was performed.

\section{RESULTS}

Three doses, $50 \mathrm{mg} / \mathrm{kg}, 200 \mathrm{mg} / \mathrm{kg}$, and 1000 $\mathrm{mg} / \mathrm{kg}$, of CZ48 were chosen for studying the plasma concentrations of CZ48 and its metabolite CPT. Three groups of female nude mice with equal numbers of animals in each group and also of similar age and weight were 
orally administered three doses of CZ48 in a manner of one group with one dose. The blood was drawn by using a cardiac puncture procedure from the animals at each time point for a time period of 24 hours. A concentration versus time curve was obtained as shown in Figure 2. The corresponding mean $\pm \mathrm{SD}$ data of each time point for all these three doses are shown in Table 1. Similarly, two groups of female nude mice were used to determine the plasma levels of CPT from the plain CPT. One group was orally administered at the maximum tolerated dose $(6 \mathrm{mg} / \mathrm{kg})$ and other at the effective anticancer dose $(1.5 \mathrm{mg} / \mathrm{kg})$. Figure 3 shows the concentration changes of CPT in plasma at each time point within 24 hours. Important PK parameters were calculated according to Figures 2 and 3 and are listed in Tables 2 and 3.

The excretion study was performed for 4 different CZ48 doses, $100 \mathrm{mg} / \mathrm{kg}, 500 \mathrm{mg} / \mathrm{kg}$, $1000 \mathrm{mg} / \mathrm{kg}$, and $2000 \mathrm{mg} / \mathrm{kg}$. A group of 3 nude mice was used for each dose. The feces collected for a period of $24 \mathrm{~h}$ after the drug administration was extracted with dichloromethane. The combined extracts were analyzed with our established HPLC procedure.
To validate the assay, a blank experiment was perforned by mixing $100 \mu \mathrm{g}$ of CZ48 with $50 \mathrm{mg}$ of dry feces. The recovery of CZ48 for this blank experiment was $108.79 \pm 7.71 \%$. The blank studies were also performed similarly for $10 \mu \mathrm{g}$ and $500 \mu \mathrm{g}$ of CZ48 and the corresponding recoveries were $103.36 \pm 1.32 \%$ and $95.84 \pm 0.76 \%$, respectively. The calibration curve was linear $(r=0.9999)$ for CZ48 ranging from 10 to $500 \mu \mathrm{g}$. The assay had an accuracy of $>95 \%$ and intra- and inter-day precision (RE\%) of $<1 \%$ for three concentrations $(10,100$, and $500 \mu \mathrm{g})$. The excretion results for 4 doses are summarized in Table 4.

To understand why CZ48 was significantly more stable in solution relative to $\mathrm{CPT}$, the geometries of CPT and CZ48 were optimized using the Gaussian03 program at the B3LYP/6$31 \mathrm{G}^{*}$ level. The optimized geometries are depicted in Figure 4. The distance between the hydrogen atom of the hydroxyl group and the carbonyl oxyegn of the closest ketone in the optimized structure of CPT was found to be $2.007 \AA$. Comparatively, no atom in CZ48 approaches a distance shorter than $2.962 \AA$ to the corresponding carbonyl oxygen.

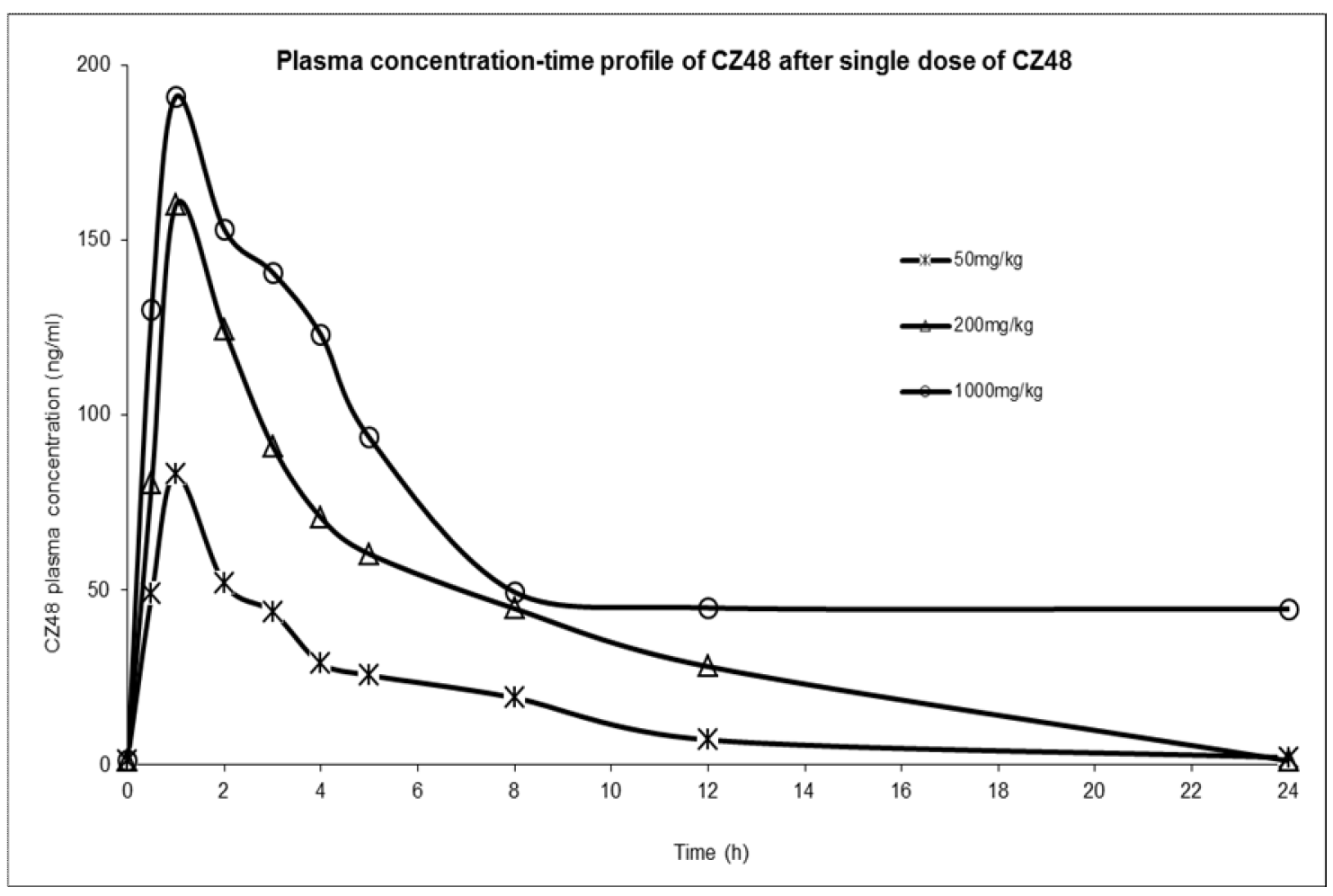




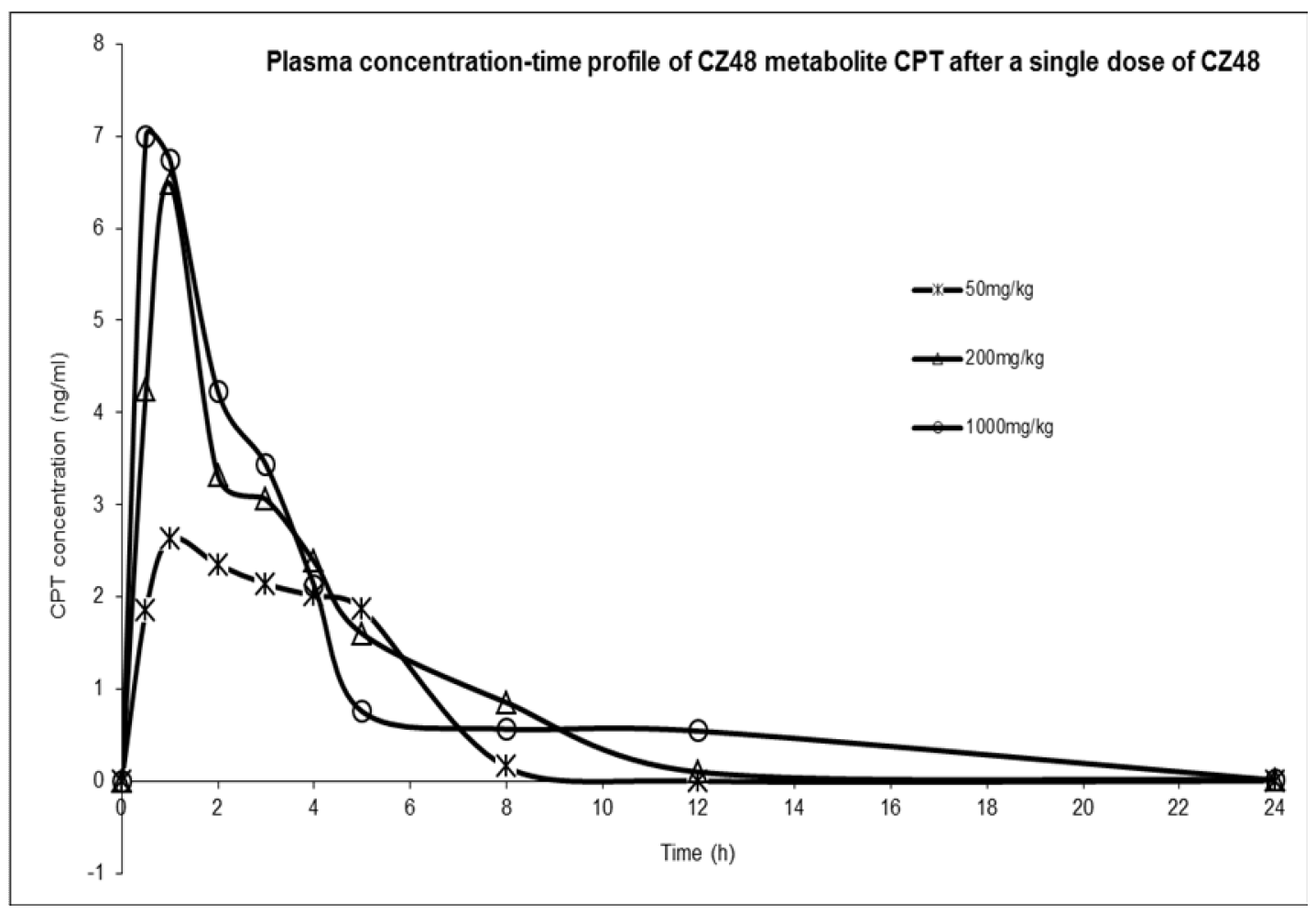

Figure2. The concentration changes of CZ48 and its metabolite CPT with time (top CZ48, bottom CPT). Data are presented as the mean $(\mathrm{n}=3)$. An ANOVA analysis on $\mathrm{C}_{\max }$ and $\mathrm{AUC}$ of each dose level was performed, $P<0.05$, one dose versus another.

\begin{tabular}{llll}
\multicolumn{4}{c}{ Table 1. Mean plasma concentration $(\mathrm{ng} / \mathrm{ml}) \pm \mathrm{SD}$ of all time points of $3 \mathrm{CZ} 48$ doses } \\
\hline \multicolumn{4}{c}{ Mean CZ48 $(\mathrm{ng} / \mathrm{mL}) \pm \mathrm{SD}$} \\
Hours & $50 \mathrm{mg} / \mathrm{kg}$ & $200 \mathrm{mg} / \mathrm{kg}$ & $1000 \mathrm{mg} / \mathrm{kg}$ \\
0 & 0.00 & 0.00 & 0.00 \\
0.5 & $48.77 \pm 27.76$ & $80.51 \pm 16.74$ & $130.05 \pm 39.05$ \\
1 & $82.99 \pm 31.35$ & $159.99 \pm 26.86$ & $190.90 \pm 0.48$ \\
2 & $51.84 \pm 14.41$ & $124.40 \pm 12.18$ & $153.03 \pm 33.45$ \\
3 & $43.71 \pm 4.11$ & $91.08 \pm 6.71$ & $140.70 \pm 37.61$ \\
4 & $28.95 \pm 8.38$ & $70.63 \pm 6.94$ & $122.81 \pm 32.83$ \\
5 & $25.65 \pm 16.12$ & $60.28 \pm 10.50$ & $93.48 \pm 13.04$ \\
8 & $19.22 \pm 11.99$ & $44.71 \pm 5.48$ & $49.40 \pm 10.42$ \\
12 & $7.20 \pm 3.95$ & $28.14 \pm 10.97$ & $44.92 \pm 25.63$ \\
24 & $2.13 \pm 0.92$ & $1.20 \pm 0.00$ & $44.61 \pm 17.19$ \\
\hline \multicolumn{4}{c}{ Mean CPT $(\mathrm{ng} / \mathrm{mL}) \mathrm{SD}$} \\
\hline 0 & 0.00 & 0.00 & 0.00 \\
0.5 & $1.86 \pm 1.45$ & $4.24 \pm 1.41$ & $7.00 \pm 3.92$ \\
1 & $2.63 \pm 0.36$ & $6.48 \pm 2.15$ & $6.74 \pm 1.85$ \\
2 & $2.35 \pm 0.51$ & $3.31 \pm 0.91$ & $4.22 \pm 1.63$ \\
3 & $2.14 \pm 0.21$ & $3.06 \pm 1.51$ & $3.43 \pm 1.94$ \\
4 & $2.01 \pm 0.50$ & $2.38 \pm 0.90$ & $2.12 \pm 3.03$ \\
5 & $1.86 \pm 0.15$ & $1.60 \pm 0.27$ & $0.75 \pm 0.91$ \\
8 & $0.15 \pm 0.07$ & $0.85 \pm 0.09$ & $0.56 \pm 0.98$ \\
12 & 0.00 & $0.10 \pm 0.24$ & $0.54 \pm 0.77$ \\
24 & 0.00 & $0.01 \pm 0.00$ & $0.01 \pm 0.00$ \\
\hline
\end{tabular}




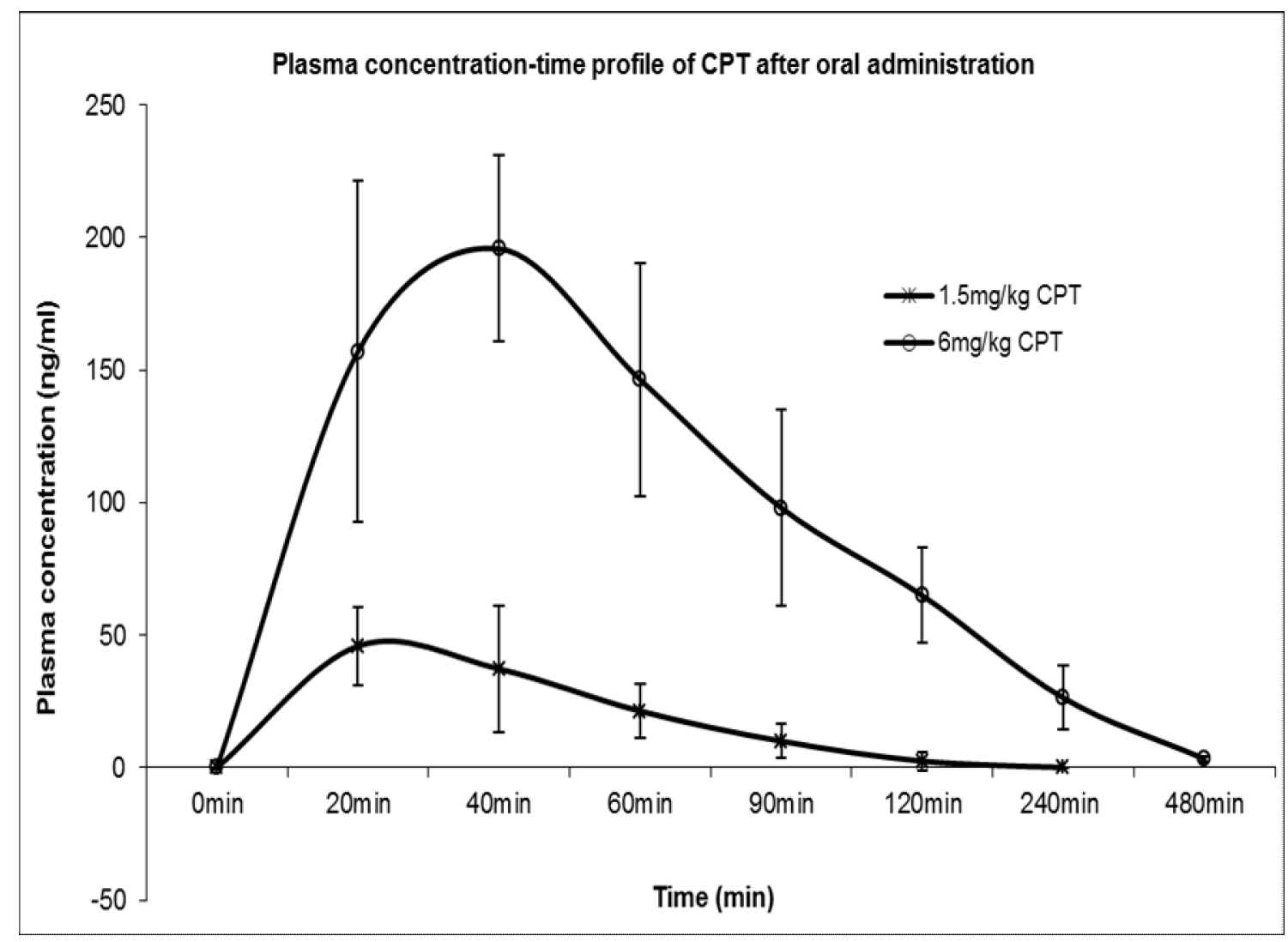

Figure 3. The concentration changes of CPT from plain CPT in mouse plasma with time. Data are presented as the mean $\pm \mathrm{SD}(\mathrm{n}=3)$.

Table 2. Pharmacokinetic parameters of CZ48 and its metabolite CPT in mouse for 3 CZ48 doses (mg/kg)

\begin{tabular}{lllllll}
\hline & & & $\mathrm{CZ48}$ & & & \\
Dose & $\mathrm{C}_{\max }(\mathrm{ng} / \mathrm{mL})$ & $\mathrm{T}_{\max }(\mathrm{h})$ & & $\mathrm{t}_{1 / 2}(\mathrm{~h})$ & $\mathrm{K}_{\mathrm{e}}(1 / \mathrm{h})$ & $\mathrm{AUC}_{0-\mathrm{t}}(\mathrm{ng} \cdot \mathrm{mL}-1)$ \\
50 & 83.00 & 1.0 & & 9.7 & 0.1 & 410.10 \\
200 & 160.00 & 1.0 & & 16.3 & 0.0 & 979.40 \\
1000 & 190.90 & 1.0 & & 24.9 & 0.0 & 1678.00 \\
& & & $\mathrm{CPT}$ & & & \\
50 & 2.6 & 1.0 & & 1.3 & 0.5 & 11.3 \\
200 & 6.5 & 1.0 & & 4.1 & 0.2 & 22.4 \\
1000 & 7.0 & 0.5 & & 6.0 & 0.1 & 70.1 \\
\hline
\end{tabular}

\begin{tabular}{llllll}
\hline \multicolumn{6}{l}{ Table 3. Pharmacokinetic parameters of plain CPT in mouse (2 dosages, $\mathrm{mg} / \mathrm{kg})$} \\
\hline Dose & $\mathrm{C}_{\max }(\mathrm{ng} / \mathrm{mL})$ & $\mathrm{T}_{\max }(\mathrm{h})$ & $\mathrm{t}_{1 / \mathrm{h}}(\mathrm{h})$ & $\mathrm{K}_{\mathrm{e}}(1 / \mathrm{h})$ & AUC0-t (ng.mL-1) \\
1.5 & 45.9 & 20 & 0.5 & 1.4 & 44.7 \\
6.0 & 195.7 & 40 & 1.3 & 0.6 & 394.4 \\
\hline
\end{tabular}

\begin{tabular}{lcccc}
\hline Table 4. The fecal content (\%dose \pm s.d. $\%)$ & of CZ48 in mouse $24 \mathrm{~h}$ after adminstration \\
\hline Dose $(\mathrm{mg} / \mathrm{kg})$ & 100 & 500 & 1000 & 2000 \\
$\mathrm{CZ} 48 \% \pm \mathrm{SD} \%$ & $78.20 \pm 10.73$ & $95.51 \pm 5.59$ & $88.14 \pm 9.11$ & $87.89 \pm 7.66$ \\
\hline a. CZ48 was almost non-detectable after $24 \mathrm{~h}$ (only $0.53 \pm 0.50 \%$ detected from 24 to $48 \mathrm{~h}$ for dose $2000 \mathrm{mg} / \mathrm{kg})$. \\
\hline
\end{tabular}




\section{(A) CPT}
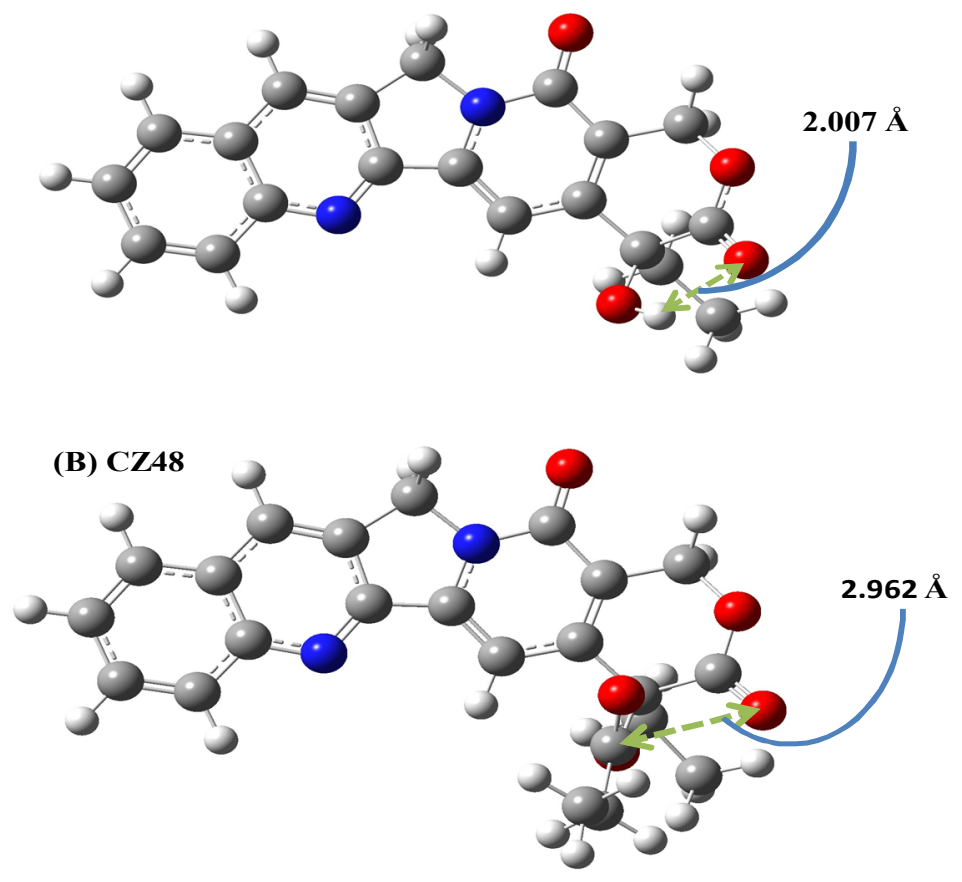

Figure 4. Geometries of CPT (A) and CZ48 (B) optimied at the B3LYP/6-31G* level.

\section{DISCUSSION}

Plasma concentrations of CZ48 and CPT were analyzed by HPLC after the oral administration of a single dose in nude mice. A recovery study was performed for CZ48 and for CPT in order to validate the assay. This study gave a recovery of $86.0 \%$ for CZ48 and $77 \%$ for CPT. Assay was reliable for the determination of CZ48 and CPT levels in mouse plasma. The calibration curve was linear $(\mathrm{r} 2=0.9999)$ over CZ48 and CPT concentrations ranging from 5 to $100 \mathrm{ng} / \mathrm{ml}$ and 10 to $1000 \mathrm{ng} / \mathrm{ml}(\mathrm{n}=6)$, respectively. The method had an accuracy of $>95 \%$ and intra- and inter-day precision (RE\%) of $<1.2 \%$ and $<2.2 \%$ for CZ48 and CPT, respectively, at three different concentrations (10, 100, and 900 $\mathrm{ng} / \mathrm{ml}$ ). The lower limit of quantification (LLOQ) using $0.1 \mathrm{ml}$ mouse plasma was $10 \mathrm{ng} / \mathrm{ml}$ for CZ48 and $5 \mathrm{ng} / \mathrm{ml}$ for CPT. Figure 2 (top) shows a dose-dependence pattern for the concentration changes of CZ48 in mouse plasma as the dose increases from $50 \mathrm{mg} / \mathrm{kg}$ to $1000 \mathrm{mg} / \mathrm{kg}$. This is especially clear from the calculated $\mathrm{C}_{\max }$ according to Figure 2. Table 2 shows that the $\mathrm{C}_{\max }$ of CZ48 increases from $83.0 \mathrm{ng} / \mathrm{ml}$ to 160.0 $\mathrm{ng} / \mathrm{ml}$ and then to $190.9 \mathrm{ng} . \mathrm{ml}$ when the dose increases from $50 \mathrm{mg} / \mathrm{kg}$ to $200 \mathrm{mg} / \mathrm{kg}$ and then to $1000 \mathrm{mg} / \mathrm{kg}$. The same was also observed for the metabolite CPT. Calculated $\mathrm{C}_{\max }(\mathrm{ng} / \mathrm{ml})$ of CPT changes from 2.6 to 6.5 , and to 7.0 , when the dose $(\mathrm{mg} / \mathrm{kg})$ increases from 50 to 200 , and to 1000 as shown in Table $1 . \mathrm{T}_{\max }$ is not dosedependent and is 1 hour (h) for CZ48 and 0.5 to $1 \mathrm{~h}$ for the metabolite CPT for all 3 doses. The elimination of the metabolite CPT from mouse blood is faster than with the mother compound CZ48. The $\mathrm{T}_{1 / 2} \mathrm{~S}$ (elimination half-life) of CPT for 3 doses range from 1.3 to $6.0 \mathrm{~h}$; while the $\mathrm{T}_{1 / 2} \mathrm{~S}$ of CZ48 are from 9.7 to $24.9 \mathrm{~h}$, implying that CZ48 stays much longer than its metabolite CPT in mouse blood. Interestingly, the $t_{1 / 2}$ of CZ48 increased significantly when the dose increased from $50 \mathrm{mg} / \mathrm{kg}$ to $1000 \mathrm{mg} / \mathrm{kg}$ and so did CPT. The CPT compounds circulating in mouse blood are generally eliminated by urine through kidney. Due to the limitation of the capacity, a mouse kidney can only allow a certain amount of the drug to pass through at a certain time period. Thus, higher concentration detected and longer $\mathrm{t}_{1 / 2}$ calculated.

The plain CPT alone resulted in significantly higher plasma concentrations as shown in Figure 3. In our laboratory, the maximum tolerated dose 
in nude mice for plain CPT is $6 \mathrm{mg} / \mathrm{kg}$. At this dose level, the $\mathrm{C}_{\max }$ of CPT was found to be $195.7 \mathrm{ng} / \mathrm{ml}$ at the time point of 40 minutes. It is commonly accepted for researchers in the field that CPT lactone opens to form CPT carboxylate in both mouse and human blood. The ratio of lactone to carboxylate is 50:50 for the mouse and approximately 5:95 for humans. The lactone form of the CPT molecule is the active form. The molecule of CPT loses its anticancer activity, but maintains most of the toxicity, when its lactone opens. CZ48 is very stable in mouse blood with only a very small fraction metabolized into CPT. Compared to plain CPT, the concentrations of the metabolite CPT measured for 3 CZ48 doses are much lower than the levels required for toxicity. For example, the CZ48 dose of $1000 \mathrm{mg} / \mathrm{kg}$ had a $\mathrm{C}_{\max }$ value of $5.6 \mathrm{ng} / \mathrm{ml}$ calculated for the metabolite CPT, which was roughly $3 \%$ of the $\mathrm{C}_{\max }$ calculated for the maximum tolerated dose of plain CPT. On the other hand, CZ48 stays intact as the lactone form when in circulation. For example, the $\mathrm{C}_{\max }$ ratio of CZ48 to CPT was 26:1 for dose 1000 $\mathrm{mg} / \mathrm{kg}, 36: 1$ for dose $200 \mathrm{mg} / \mathrm{kg}$, and $87: 1$ for dose $50 \mathrm{mg} / \mathrm{kg}$. In other words, $96 \%$ or more of the drug in mouse blood are lactone CZ48. This stability of CZ48 in blood ensures that the molecule is capable of delivering sufficient lactone CPT into tumor sites to kill the cancer cells. Thus, we achieved a $97 \%$ response rate (28 out of 29) with CZ48 in treating 29 human xenografts grown in nude mice (29), while the toxicity of CZ48 in mice was minimal. Healthy animals in a test groups received CZ48 in suspension form daily by gavage for 280 days post-treatment initiation at a dose of $2000 \mathrm{mg} / \mathrm{kg}$ (27). We did not find any significant bodyweight losses at all during this long treatment; in fact, the average body weight of these treated mice increased slightly, as did the control animals. Surprisingly, the elimination of CPT from blood for plain CPT was found to be much faster than the CPT metabolized from CZ48. The elimination $t_{1 / 2}$ of CPT for the 2 doses of plain CPT was $0.5 \mathrm{~h}$ and $1.3 \mathrm{~h}$, respectively, while this value for the 3 doses of CZ48 was 1.3 $\mathrm{h}, 4.1 \mathrm{~h}$, and $6.0 \mathrm{~h}$, respectively. This may be due to that the local environment in blood for metabolite CPT differing from the plain CPT.
It was also observed that the absorption of CZ48 in mice was much poorer than the plain CPT. Plain CPT could generate a $\mathrm{C}_{\max }$ value of $195.7 \mathrm{ng} / \mathrm{ml}$ with a dose of $6 \mathrm{mg} / \mathrm{kg}$, while CZ48 only gave a $\mathrm{C}_{\max }$ of $190.9 \mathrm{ng} / \mathrm{ml}$ for dose of 1000 $\mathrm{mg} / \mathrm{kg}$. The bioavailability of CZ48 in the mouse is low and the majority of the drug is excreted in the feces. The results of the excretion studies (table 4) shows that almost $90 \%$ of CZ48 are detected in the feces during $24 \mathrm{~h}$ post administration. Obviously, to increase the bioavailability of CZ48 by changing the formulations of the drug may further increase its potency against cancers.

The stability of CZ48 compared to CPT can be primarily attributed to the $2.007 \AA$ distance between the hydroxyl hydrogen and the carbonyl oxygen of the closest ketone. $2.007 \AA$ is well within hydrogen bonding distance; the attraction the hydrogen exerts over the carbonyl oxygen increases the vulnerability of the attached carbon and subsequently decreases the activation energy. The dominant hydrolytic pathway of carboxylic acid ester is based on nueclophilic attack by hydroxide; the $\pi$-bond of the carbonyl group is gradually broken during the reaction process and pulled towards the oxygen, increasing the partial negative charge on the oxygen over time (32-34). The importance of the hydrogen bond is that as the partial negative charge of the oxygen increases, the attraction between the hydrogen and oxygen increases, contributing to the stabilization of the transition state. This results in decrease of activation energy known as intramolecular catalysis (35). This decrease in activation energy is inversely related to the hydrolytic rate of $\mathrm{CPT}$, leading to the low concentration of CPT in blood after a short period of time. The CZ48, however, does not display hydrogen bonding; the transition state in this case can be assumed to be of much higher energy, therefore resulting in the significantly lower reaction rate and comparatively high blood concentration over the same period of time.

\section{CONCLUSION}

CZ48, the protected form of camptothecin, greatly increases the lactone stability of the camptothecin molecule in mouse blood. CZ48 
molecule stays intact as the lactone form when in circulation and metabolizes into active metabolite CPT after entering into tumor cells. This enhanced stability of the CZ48 molecule in blood makes it highly effective against various human xenografts grown in nude mice with minimum toxicity. The absorption of this agent in mice is low. To increase the bioavailability, CZ48 needs to be formulated differently from its current form, which may further improve the effectiveness of this agent against cancers.

\section{ACKNOWLEDGEMENT}

The financial support from CHRISTUS Health and the Friends of CHRISTUS Stehlin Foundation for Cancer Research is greatly acknowledged.

\section{REFERENCES}

1. Pommier Y, Leo E, Zhang H, Marchand C. DNA topoisomerases and their poisoning by anticancer and antibacterial drugs. Chem Biol, 2010; 17: 421-433.

2. Koster DA, Crut A, Shuman S, Bjornsti MA, Dekker NH. Cellular strategies for regulating DNA supercoiling: A single-molecule perspective. Cell, 2010; 142: 519-530.

3. Pommier Y. DNA topoisomerase I inhibitors: Chemistry, biology, and interfacial inhibition. Chem Rev, 2009; 109: 2894-2902.

4. Huinink W, Gore M, Carmichael J, Gordon A, Malfetano J, Hudson I, Broom C, Scarabelli C, Davidson N, Spanczynski M, Bolis G, Maimstrom H, Coleman R, Fields C, Heron F. Topotecan versus paclitaxel for the treatment of recurrent epithelial ovarian cancer. J Clin Oncol, 1997; 15: 2183-2193.

5. Schiller JH, Adak S, Cella D, DeVore RF, Johnson DH. Topotecan versus observation after cisplatin plus etoposide in extensive-stage smallcell lung cancer: E7593-A phase III trial of the Eastern Cooperative Oncology Group. J Clin Oncol, 2001; 19: 2114-2122.

6. Von Pawel J, Schiller JH, Shepherd FA, Shepherd FA, Fields SZ, Kleisbauer JP, Chrysson NG, Stewart DJ, Clark PI, Palmer MC, Depierre A, Carmichael J, Krebs JB, Ross G, Lane SR, Gralla R. Topotecan versus cyclophosphamide, doxorubicin, and vincristine for the treatment of recurrent small-cell lung cancer. J Clin Oncol, 1999; 17: 658-667.
7. Pizzolato JF, Saltz LB. The camptothecins. Lancet, 2003; 361: 2235-2242.

8. Saltz LB, Cox JV, Blanke C, Rosen L, Fehrenbacher L, Moore M, Maroun J, Ackland S, Locker P, Pirotte N, Elfring G, Miller L. Irinotecan plus fluorouracil and leucovorin for metastatic colorectal cancer. N Engl J Med, 2002; 343: 905-914.

9. Douillard JY, Cunningham D, Roth AD, Navarro M, James RD, Karasek P, Jandik P, Iveson T, Carmichael J, Alakl M, Gruia G, Awad L, Rougier P. Irinotecan combined with fluorouracil compared with fluorouracil alone as first-line treatment for metastatic colorectal cancer: a multicenter randomized trial. Lancet, 2000; 355: 1041-1047.

10. Blandizzi C, Paolis BD, Colucci R, Lazzeri G, Baschiera F, Tacca MD. Characterization of a novel mechanism accounting for the adverse cholinergic effects of the anticancer drug irinotecan. British Journal of Pharmacology. British J Pharm, 2001; 132: 73-84.

11. Abigerges D, Chabot GG, Armand JP, Hérait $P$, Gouyette A, Gandia D. Phase I and pharmacologic studies of the camptothecin analog irinotecan administered every 3 weeks in cancer patients. J Clin Oncol, 1995; 13(1): 21021.

12. Gupta E, Lestingi TM, Mick R, Ramirez J, Vokes EE, Ratain MJ. Metabolic Fate of Irinotecan in Humans: Correlation of Glucuronidation with Diarrhea. Cancer Res, 1994; 54: 3723-3725.

13. Ratain MJ. Irinotecan dosing: does the CPT in CPT-11 stand for "can't predict toxicity". J Clin Oncol, 2002; 20: 7-8.

14. Saltz L, Sirott M, Young Y, Tong W, Niedzwiecki D, Yao TJ, Tao Y, Trochanowski B, Wright P, Barbosa K, Toomasi F, Kelsen D. Phase I Clinical and Pharmacology Study of Topotecan Given Daily for 5 Consecutive Days to Patients With Advanced Solid Tumors, With Attempt at Dose Intensification Using Recombinant Granulocyte Colony-Stimulating Factor. J Natl Cancer Inst, 1993; 85: 1499-1507.

15. Burke TG. Chemistry of the camptothecins in the bloodstream: drug stabilization and optimization of activity (The Camptothecins - From Discovery to Patients). Ann NY Acd Sci, 1993; 803: 29-31.

16. Mi Z, Burke TG. Marked interspecies variations concerning interactions of camptothecin with serum albumin. Biochemistry, 1994; 33: 12401245. 
17. Thomas CJ, Rahier NJ, Hecht SM. Camptothecin: current perspectives. Bioorg Med Chem 2004; 12: 1585-604.

18. Zunino F, Pratesi G. Camptothecins in clinical development. Exp Opin Investig Drugs, 2004; 13: 269-84.

19. Beretta GL, Zunino F. Relevance of extracellular and intracellular interactions of camptothecins as determinants of antitumor activity. Biochem Pharmacol, 2007; 74: 1437-44.

20. Beretta GL, Perego P, Zunino F. Mechanisms of cellular resistance to camptothecins. Curr Med Chem, 2006; 13: 3291-305.

21. Burke TG, Munshi CB, Mi Z, Jiang Y. The important role of albumin in determining the relative human blood stabilities of the camptothecin anticancer drugs. J Pharm Sci, 1995; 84: 518-9.

22. Garcia-Carbonero R, Supko JG. Current perspectives on the clinical experience, pharmacology, and continued development of the camptothecins. Clin Cancer Res, 2002; 8(3): 641-61.

23. Cao Z, Harris N, Kozielski A, Vardeman D, Stehlin J, Giovanella B. Alkyl esters of camptothecin and 9-nitrocamptothecin: Synthesis, in vitro pharmacokinetics, toxicity, and antitumor activity. J Med Chem, 1998; 41: 31-37.

24. Cao Z, Mendoza J, DeJesus A, Giovanella B. Synthesis and antitumor activity of alkenyl camptothecin esters. Acta Pharmacologica Sinica, 2005; 26: 235-241.

25. Cao Z, Mendoza J, DeJesus A, Vardeman D, Giovanella B. Synthesis and antitumor activity of aromatic camptothecin esters. Int $\mathrm{J}$ Mol Med, 2008; 21: 477-487.

26. Cao Z, Mendoza J, Kozielski A, Liu X, DeJesus A, Wang Y, Vardeman D, Giovanella B. Anticancer activity of new haloalkyl camptothecin esters against human cancer cell lines and human tumor xenografts grown in nude mice. Anti-Cancer Agents in Med Chem, 2012; 12(10): 818-828.

27. Cao Z, Kozielski A, Liu X, Wang Y, Vardeman D, Giovanella B. Crystalline camptothecin20(S)-O-propionate hydrate: A novel anticancer agent with strong activity against 19 human tumor xenografts. Cancer Research, 2009; 69 (11): 4742-4749.

28. Liu X, DeJesus A, Cao Z, Vardeman D, Giovanella B. Metabolic difference of CZ48 in human and mouse liver microsomes. Int $\mathrm{J}$ Mol Sci, 2012; 13: 5498-5505.

29. Liu X, Cao Z, Mendoza J, Vardeman D, Giovanella B. The Relationship between the sensitivity of the tumors to treatment with CZ48 and the local concentrations of the active metabolite CPT inside the tumors. Biomedical Reports, 2013; 1: 202-206

30. Liu X, Wang Y, Vardeman D, Cao Z, Giovanella B. Development and validation of a reversephase HPLC with fluorescence detector method for simultaneous determination of CZ48 and its active metabolite camptothecin in mouse plasma. Journal of Chromatography B, 2008; 867: 84-89.

31. Frisch M J, Trucks GW, Schlegel HB, Scuseria GE, Robb MA, Montgomery JA, Vreven T, Udin KN, Burant JC, Millam JM, Yengar SS, Tomasi J, Barone V, Mennucci B, Cossi M, Scalmani G, Rega N, Petersson GA, Nakatsuji H, Hada M, Ehara M, Toyota K, Fukuda R, Hasegawa J, shida M, Nakajima T, Honda Y, Kitao O, Nakai $\mathrm{H}$, Klene M, Li X, Knox JE, Hratchian HP, Cross JB, Bakken V, Adamo C, Jaramillo J, Gomperts R, Stratmann RE, Yazyev O, Austin AJ, Cammi R, Pomelli C, Ochterski JW, Ayala PY, Morokuma K, Voth GA, Salvador P, Dannenberg JJ, Zakrzewski VG, Dapprich S, Daniels AD, Strain MC, Farkas O, Malick DK, Rabuck AD, Raghavachari K, Foresman JB, Ortiz JV, Cui Q, Baboul AG, Clifford S, Cioslowski J, Stefanov BB, Liu G, Liashenko A, Piskorz P, Komaromi I, Martin RL, Fox DJ, Keith T, Al-Laham MA, Peng CY, Nanayakkara A, Challacombe M, Gill PMW, Johnson B, Chen W, Wong MW, Gonzalez C, Pople JA. Gaussian 03, Version C.02; Gaussian, Inc.: Wallingford, CT, 2004.

32. Zhan CG, Landry DW, Ornstein RL. Reaction pathways and energy barriers for alkaline hydrolysis of carboxylic acid esters in water studied by a hybrid supermolecule-polarizable continuum approach. J Am Chem Soc, 2000; $122 ; 2621-2627$.

33. Zhan CG, Landry DW, Ornstein RL. Energy barriers for alkaline hydrolysis of carboxylic acid esters in aqueous solution by reaction field calculations. J Phys Chem A, 2000; 104: 76727678.

34. Zhan CG, Landry DW. Theoretical studies of competing reaction pathways and energy barriers for alkaline ester hydrolysis of cocaine. J Phys Chem A, 2001; 105: 1296-1301.

35. Zhan CG, Deng SX, Skiba JG, Hayes BA, Tschampel SM, Shields GC, Landry DW. Firstprinciple studies of intermolecular and intramolecular catalysis of protonated cocaine, J. Comput Chem, 2005; 26: 980-986. 